\title{
KEPRIBADIAN DAN AKTUALISASI DIRI TOKOH UTAMA DALAM KUMPULAN CERPEN SEMUA UNTUK HINDIA KARYA IKSAKA BANU (KAJIAN PSIKOLOGI SASTRA)
}

\author{
AH Khuzaini \\ SD Negeri Kediren Kalitengah Lamongan \\ Telp.085731532005; Pos-el djenar33@gmail.com
}

\begin{abstract}
Abstrak: Penelitian ini dilakukan dengan tujuan untuk mendeskripsikankepribadian dan aktualisasi diri tokoh utama dalam kumpulan cerpen semua untuk hindia karya iksaka banu (kajian) psikologi sastra. Data dikumpulkan dengan metode simak dan catat melalui penelitian kualitatif. Temuan penelitian menunjukan bahwa. (1) Tokoh utama berkebangsaan Belanda yang memiliki kepribadian berbeda dengan bangsa belanda pada umumnya terhadap bangsa pribumi (2) Konflik yang dirasakan tokoh utama sebagian besar bermula dari benturan prinsip dengan sesama warga Belanda (3) Tokoh utama memiliki perhatian yang besar terhadap kepentingan dan kebaikan pribumi.
\end{abstract}

Kata-kata kunci: kepribadian, aktualisasi diri, tokoh utama.

Abstract: His research was conducted with the aim to describe the personality and selfactualization of the main character in a collection of short stories all for Hindi iksaka banu (study) literary psychology. The data was collected using the reading method and recorded through qualitative research. Research findings show that. (1) The main figure of Dutch nationality who has a different personality from the Dutch in general towards the indigenous people (2) The conflict that was felt by the main character mostly started from a clash of principles with fellow Dutch citizens (3) The main character had great attention to the interests and goodness indigenous

Keywords: personality, self-actualization, the main character.

\section{PENDAHULUAN}

Cerita pendek sebagai salah satu genre karya sastra Indonesia modern mempunyai fungsi dalam kehidupan manusia, di antaranya menggambarkan situasi dan kondisi kemanusiaan, kepekaan batin atau sosial, kecerdasan, dan kesejahteraan rohani. Hal ini sejalan dengan pendapat Sumardjo (1988:16) bahwa sebagai cabang kesenian, berfungsi memperjelas, memperdalam, dan memperkaya penghayatan manusia terhadap kehidupan mereka.

Telah diketahui bahwa sejarah merupakan bagian dari sebuah realitas sosial yang ada di dalam kehidupan masyrakat sehingga tidak aneh jika peristiwa sejarah digunakan sebagai inspirasi bagi para pengarang. Terlebih lagi peristiwa sejarah yang sangat besar dan fenomenal seperti masa kolonial Belanda di Indonesia. Penciptaan karya sastra tidak akan pernah lepas dari realitas kehidupan sosial manusia. Wellek dan Waren (2012:98) berpendapat bahwa sastra mampu menyajikan kehidupan, dan kehidupan itu sendiri terdiri dari kenyataan sosial meskipun karya sastra 
merupakan tiruan alam dan penuh dengan subjektivitas manusia.

Tidak sedikit pengarang yang menggunakan masa kolonial Belanda sebagai inspirasi penulisan karyanya seperti novel Jalan Raya Pos, Jalan Daendels karya Pramoedya Ananta Toer, Max Havelaar karya Multatuli, Babad Dipanegara karya Dipanegara, dan Burung-Burung Manyar karya Y.B Mangunwijaya.

Penggunaan tema masa kolonial Belanda di dalam karya sastra bukanlah tanpa alasan. Masa penjajahan kolonial Belanda di Indonesia terjadi dalam kurun waktu yang sangat lama, dan sepanjang tiga setengah abad itu pula banyak peristiwa-peristiwa yang terjadi. Baik peperangan, pemberontakan, pembantaian, dan peristiwa lainnya yang melibatkan berbagai pihak yang berada di tanah Indonesia sehingga banyak penciptaan karya sastra yang bertolak dari peristiwa-peristiwa tersebut. Djamaris (2007:1)

Salah satu karya sastra sejarah yang cukup diperhitungkan kehadiranya ialah Kumpulan cerpen Semua untuk Hindia karya Iksaka Banu. Karya sastra ini merupakan kumpulan cerita pendek yang seluruh penceritaannya merentang dari masa kedatangan Cornelis de Houtman pada 1596 hingga masa-masa awal Indonesia merdeka. Masing-masing diceritakan dari sudut pandang tokohtokoh utamanya yang beragam seperti wartawan perang, polisi, tentara, pastor, administratur perkebunan tembakau, dokter tentara, hingga seorang Nyai. Yang membuat kisah-kisah dalam buku ini menjadi menarik adalah hampir semua konflik yang terjadi pada tokoh-tokohnya terkait dengan peristiwa-peristiwa dan tokoh-tokoh sejarah yang pernah terjadi pada masa kolonialisme.

Dari dua belas tokoh dalam cerita ini memiliki darah Eropa namun mereka dikonstruksikan oleh penulisnya memiliki sisi kemanusian yang tinggi pada orangorang di tanah jajahan tersebut. Posisi si "aku" yang seorang berpendidikan Barat tetap dalam kerangka seorang penjajah, tanpa terjebak menjadi sosok eksploitatifataupenyelamat. Dalam ceritanya, Iksaka Banu menunjukkan bahwa dalam posisiterjajah, bukan berarti apa yang dilakukan orang "Indonesia" pasti benar.

Tidak semua cerpen yang terdapat di dalam buku Semua untuk Hindia akan dijadikan sebagai objek kajian penelitian, dari tiga belas cerpen yang ada penulis hanya akan memilih enam cerpen untuk dianalisis. Enam cerpen tersebut ialah "Selamat Tinggal Hindia (2012)"Bintang Jatuh" (2012) Keringat Dan Susu (2010) "Gudang nomor 012B" (2011). Semua Untuk Hindia (2008), dan Tangan Ratu Adil (2014).

Adapun alasan peneliti memilih enam cerpen tersebut berdasarkan kekuatan kepribadian dan konflik batin yang dialami para tokoh utama serta usaha aktualisasi mereka yang lebih kental dan meluas kepada pada pribumi daripada tokoh utama dalam cerpen lain.

Kekuatan aktualisasi diri tokoh utama bagi kebaikan pribumi bisa kita lihat semisal dalam cerita pendek berjudul selamat tinggal Hindia. Diperlihatkan usaha tokoh utama melindungi guru sekolah berkebangsaan Belanda melanjutkan pengabdiannya untuk memajukan pendidikan bangsa Indonesia yang baru merdeka. Tokoh utama dalam cerpen berjudul keringat dan susu bernama Pieter. Pieter adalah seorang Letnan yang melindungi pembunuhan yang dilakukan pasukannya kepada pemuda pribumi yang gila menjadi tentara dan seorang Ibu yang baru melahirkan. Tokoh utama Cerpen Gudang nomor 12B, seorang Inspektur dan kepala gudang berusaha 
menyembuhkan seorang wanita miskin penderita lepra dan melindungi para kuli dari ancaman kekerasan yang dilakukan atasannya. Tokoh utama cerpen Semua untuk Hindia, seorang wartawan De locomotif yang lebih memilih melindungi rakyat Bali daripada mendukung penyerangan Bali yang dilakukan oleh negaranya. Hemat kata, keenam tokoh utama dalam cerpen yang penulis analisa adalah prtibadi yang berusaha melindungi pribumi dari penindasan. Mereka melakukan lantaran kesadaran akan kemanusiaan lebih besar daripada kekuasaan

Berdasarkan paparan di atas, perlu adanya penelitian yang bertujuan untuk (1) mendiskripsikan kepribadian tokoh utama dalam kumpulan Cerpen Semua Untuk Hindia karya Iksaka Banu dan (2) menemukan aktualisasi diri tokoh utama dalam kumpulan Cerpen Semua Untuk Hindia karya Iksaka Banu?

\section{METODE PENELITIAN}

Penelitian ini dirancang dalam bentuk penelitian deskriptif-kualitaif. Data utama penelitian ini berupa katakata, frasa, klausa, dan kalimat pada setiap paragraf dalam kumpulan Cerpen Semua untuk Hindia karya Iksaka Banu yang mengandung kepribadiam dan aktualisasi diri. Ini senada dengan pendapat Ratna (2013: 47) karya (Cerpen), naskah, data penelitiannya, sebagai data formal adalah kata-kata, kalimat, dan wacana

Pengumpulan data dalam penelitian ini menggunakan teknik simak. Menurut Mahsun (2005:126) metode simak merupakan metode pengumpulan data yang dilakukan dengan cara menyimak penggunaan bahasa.

Analisis data dilakukan dengan langkah-langkah berikut: mendiskripsikan kepribadian tokoh utama dalam kumpulan Cerpen Semua
Untuk Hindia karya Iksaka Banu (2) menemukan konflik yang dihadapi tokoh utama kumpulan Cerpen Semua Untuk Hindia karya Iksaka Banu (3) menemukan aktualisasi diri tokoh utama dalam kumpulan Cerpen Semua Untuk Hindia karya Iksaka Banu

\section{HASIL PENELITIAN \\ Kepribadian Tokoh Utama \\ Membenci Tindakan Laskar}

Sebagai seorang wartawan Martin berkali-kali melihat tindakan laskar yang memanfaatkan situasi untuk mengambil keuntungan sendiri. Dia secara terus terang mengatakan mereka sebagai

"Anak-anak haram revolusi" (Iksaka, 2014-5).

Tindakan kasar pemuda yang tergabung dalam laskar terhadap bangsa Belanda dan orang yang dianggap kolaborator, meyakinkan Martin akan suramnya masa depan negara yang baru merdeka.

\section{Tegas}

Pieter dikelilingi pasukan terpilih, mulai dari orang radio, Sersan, Kopral yang berasal dari berbagai bangsa yang kemudian masuk dalam kesatuan tentara Hindia Belanda. Pasukan Pieter memiliki kemampuan yang mumpuni dalam medan perang terutama kemampuan mengintimidasi, menciptakan teror serta merumuskan strategi penyerangan. Perbedaan karakter pasukannya seringkali membuat mereka terlibat pertentangan diantanya mereka. Namun Pieter selalu mampu mengendalikan mereka.

Sebelum melakukan operasi, seorang Kopral menyarankan agar gerakan malam itu menitiru cara Batalion 10. Pasukan militer baru yang beranggotakan mantan tentara KNIL. Mereka berkeliling kota tengah malam, berteriak-teriak sambil melepas tembakan ke atas dan menculik orang yang 
dicurigai sebagai tentara republik dan langsung membalas teror dengan teror. Meskipun strategi tersebut terdengar efektif untuk memancing tentara republik Pieter tidak segera menerima usulan itu. Sesuai kesadarannya dia memilih cara lain yang sekiranya menang perlu menumpahkan darah.

\section{Berterima Kasih kepada Pribumi}

Pengalaman masa kecilnya membuatnya dia tahu harus memberi penghormatan pada siapa. Ibu Hans seorang anak mandor kopi Limbangan yang dihamili oleh Belanda totok, setelah melahirkan, ayahnya meninggalkan Ibunya tanpa sepeser pun uang untuk membesarkannya. Sepupu ibunya yang dipanggil Mang acim menanggung keperluannya sejak kecil dan mengambil alih pekerjaan yang seharusnya menjadi tanggung jawab ayahnya.

"Setelah aku menjadi polisi, kubiarkan Mang Acim menikmati

balasjasaku"(Iksaka, 2014:58).

\section{Peduli Akan Keselamatan Rakyat Bali}

Meski berdarah Belanda De Wit terus terang mengakui telah berabad bangsa Belanda terjangkit penyakit gila kebesaran. Dia pun merasa Tuhan pun enggan mendengar doa meereka sebab sudah lama pula bangsa Belanda tak bisa menghormati kedaulatan orang lain. Dia merasa per cuma berteriak melarang. Sebab Penjarahan dilakukan bukan oleh tentara pribumi saja, para perwira Eropa pun terlibat militer.

"Sebuah peradaban tinggi akan musnah"(Iksaka, 2014:68).

De Wit memliki data valid sebagai dasar analisa sebab penyerangan militer belanda terhadap kerajaan dan rakyat Bali sehingga dia mengerti mana pihan yang benar dan salah. Dalam pandangannya, Belanda berada dipihak yang salah.

\section{Analitis}

Tokoh utama (TU) menjelaskan kepada Dirk, bila motivasi gerakan perlawanan rakyat Banten terhadap pemerintah Hindia Belanda berbeda dengan gerakan sebelumnya. Dia telah membaca semua arsip kepolisian Banten. Kota-kota di daerah ini sejak dahulu bergiliran berontak. Dan ciri pemberontakan itu sangat khas, bersifat spiritual. Mulai dari kerusuhan di Cikandi Udik, Kolelet, kasus Jayakusuma, serta tragedi dua tahun lalu, yaitu pembantaian di Ciomas.

"Sasaran mereka bukan hanya militer, melainkan semua yang mereka anggap kafir. Musuh Allah." (Iksaka, 2014:75).

Pengetahuan dan ketenangan membaca sebab -akibat sosial membuat TU memiliki cara pandang lain terhadap gerakan adil.

\section{Profesional}

$\begin{array}{lrr}\text { Goedaerd mengakui } & \text { meredam } \\ \text { perlawanan orang-orang } & \text { Tionghoa } \\ \text { bukanlah pekerjaan mudah } & \text { Mereka } \\ \text { bukan lawan sembarangan. } & \text { Jumlah } \\ \text { mereka besar dan pandai } & \text { bersiasat. }\end{array}$ Dibutuhkan disiplin tinggi para pasukan Belanda menjaga pintu masuk dan keutuhan delapanbelas meriam yang dipasang di seputar benteng batavia. Walau Goedaerd berhasil memeukul mundur para pemberontak, mereka berhasil membakar tenda peleton di kanal-kanal seputar benteng, sederet sampan berisi tiga atau lima musketier masih bersiaga sebagai lapis kedua bila gerbang benteng bobol Goedaerd memenuhi panggilan Kapten Jan Twijfels, melaporkan keberhasilannya meredam pemberontakan Tionghoa dan keputusan yang diambilnya setelah pertempuran.

"Telah kami umumkan, bahwa sejak tadi pagi, 8 Oktober 1740, penduduk Tionghoa 
dilarang pergi ke luar benteng. Dan setelah pukul 18:30, semua harus tinggal di rumah, tanpa lampu, serta secepatnya menyerahkan segala senjata kepada petugas. Tak ada perayaan Imlek tahun ini" (Iksaka, 2014:108)

Perlawanan itu membuat Gubernur Jenderal khawatir penduduk Tionghoa yang ada di dalam benteng akan terhasut dan bangkit melawan

"Apalagi Nie Hoe Kong ini tidak becus menjadi Kapten Cina. Tak punya wibawa mengatur warganya. Aku bahkan curiga, dia ada di belakang ini semua. Bukankah pemberontakan ini bermula dari persekongkolan buruh tebu miliknya?" (Iksaka, 2014:108).

Setelah menjelaskan perlawanan orang-orang Tionghoa yang meluas diberbagai tempat, Kapten Jan memerintahkan Goedaerd terlibat mengusut akar masalah. Dengan berat hati Goedaerd memenuhi perintah itu

\section{Usaha Aktualisasi Diri Tokoh Utama Menyelamatkan Guru Belanda yang mengabdikan diri kepada Pribumi}

Keingingan terbesar tokoh utama cerpen ini adalah menyelamat sebanyak mungkin orang yang bisa diselamatkan, tidak hanya bangsa Belanda dan orang kulit putih lain. Tapi juga pribumi seperti Dullah dan Iyah, wanita pribumi yang mengurus rumah Geertje. Diantara semua itu, Geertje, seorang guru yang mengajar bangsa pribumi adalah orang yang paling dia ingin diselamatkan.

Telah banyak usaha Martin untuk mengaktualisasikan kebutuhannya, mulai membantu mengantarkan ke rumahnya, membantu memasang kaca jendela dan mengantarnya ke pasar. Statusnya sebagai wartawan setidaknya bisa dia gunakan untuk melindungi Geertje. Ketika Martin tahu Geertje tidak memiliki tempat tinggal di Belanda, dia menawarkan rumahnya.

"Di kampung halamanku, di Zundert, ada beberapa rumah kontrakan dengan harga terjangkau. Sambil menunggu kabar tentang ayahmu, kau bisa tinggal di sana."(Iksaka, 2014:11)

\section{Melindungi Wanita Pribumi}

Pieter mengharapkan mampu meredam gejolak revolusi melalui pendekatan yang cerdik, bermartabat, serta menghasilkan kemenangan berskala besar.

Ada peristiwa saat Pieter mengatualisasikan dirinya untuk melindungi wanita pribumi dari kekerasan yang dilakukan pasukannya.

Pertama, Saat berangkat, pasukan Pieter membicarakan sosok gadis Sunda bernama Euisl, gadis yang sebelumnya bertemu dengan Pieter. Mereka bergantian menggoda hubungan antaran Pieter dengan gadis itu.

"Hati-hati, jangan ganggu gadis-gadis itu," kuembuskan asap rokok terakhir, lalu kuinjak puntungnya.

"Anda terdengar sangat serius, Letnan," Sersan Richmond mengokang Lee Enield-nya.

"Aku serius" (Iksaka, 2014:31)

Pieter menjelaskan bisa saja para gadis yang mereka temui adalah matamata yang disusupkan. Kecuali itu, teman-teman mereka, para fanatik, akan menjagal gadis-gadis itu bila tahu mereka punya kisah asmara dengan salah satu dari pasukannya.

\section{Menjaga Keselamatan Kuli}

Sebagai kepala Gudang, tokoh utama cerita ini bisa menggunakan kekerasan dalam mengusut kasus pencurian beras seperti saran komisarisnya

"Seorang totok akan memilih cara lebih cepat, murah, dan masuk akal:Paksa mereka berbaris. Katakan, yang menolak mengangkat barang akan dicambuk oleh teman-temannya sendiri. Betul, mereka pekerja lepas. Tapi mereka mencari makan di atas lahan Gubernemen. Kita punya hak 
bikin rapi semua urusan di sana!" (Iksaka, 2014:56)

Hans lebih memilih menyelidiki, beruntung bisa menangkap pencuri beras di gudang itu bagaimanapun caranya. Dia bahkan berniat memenuhi permintaan para kuli untuk menyelenggarakan upacara selamatan sembari membiarkan kasus pencuian beras berlalu dengan sendirinya. Salah-satu tujuan Hans melakukan penyelidikan adalah menyelamatkan kuli dari kekerasan yang bakal dilakukan Gijs kepada kuli yang tidak bersalah.

\section{Menyelamatkan Perempuan Pribumi Penderita Lepra}

Setelah melakukan penyelidikan Hans akhirnya bisa menangkap pencuri beras. Seperti yang dia duga makhluk itu jelas bukan hantu, setan, atau demit melainkan seorang wanita. Kurus kering. Merapat di sudut tembok. Rambutnya kotor, panjang hingga ke pangkal paha. dia mengenakan gaun putih mirip gaun tidur wanita Belanda.

Saat ditelikung, rambut depan wanita itu tersingkap. Hans dan semua orang yang menangkapnya melihat wanita itu menderita penyakit lepra di tahap yang paling parah hingga sulit mengenali mata, hidung, maupun mulutnya dan sedang sekarat.

"Mang Acim, besok kita kesini lagi bersama para opas. Tak mungkin dia mampu menggangsur tanah dengan kondisi tubuh semacam itu. Pasti ada komplotan yang memanfaatkan wanita ini. Cari tahu, siapa di antara para kuli yang tempo hari punya gagasan memberi sajen beras Dan Irus, tolong bikin tandu. Biarkan wanita ini menginap di penjara. Jangan lupa bersihkan tangan kalian. Besok akan kuhubungi Dokter Willem." (Iksaka, 2014:60).

\section{Menyelamatkan Gadis Bali}

De Wit sadar bila tidak mungkin baginya menghentikan penyerangan Belanda atas Bali atau menyelamatkan penduduk Bali dari dampak buruk perang. Namun setidaknya dia bisa menyelamatkan satu gadis bali yang menganggapnya sebagai kakak. Temannya sesama wartawan menyarankan

"Kalau mau bertemu gadismu, sebaiknya ikut Batalion 18 lewat Desa Kayumas" (Iksaka, 2014:69).

De Wit mengikuti saran temannya, dia pun membaur di antara pasukan, menyusuri jalan setapak dan loronglorong desa. setelah kondisi kembali sunyi semua sunyi dan kabut mesiu menipis. Barulah De Wit mendapat kesempatan mencari gadis kecil bali. Dia berlari kesetanan ke arah tumpukan mayat. Memilah-milah, mencocokkan puluhan daging dengan wajah yang bisa dia ingat namun tak satupun wajah itu mampu dia kenali.

De Wit tersentak saat mengetahui dari tumpukan mayat di sisi kanannya perlahan-lahan muncul suatu sosok. Seorang gadis kecil yang kepala sampai perutnya keluar darah. Tepat saat tangan kanannya bergerak menangkap,dia mendengar tembakan yang mengenai kepala gadis itu, seketika darah mucrat di kepalanya dan gadis itu seketika mati.

De Wit kemudia mendengar suara Jenderal Rost van Tonningen

"Berhentilah menulis hal buruk tentang kami, Nak. Aku dan tentaraku tahu persis apa yang sedang kami lakukan. Semua untuk Hindia. Hanya untuk Hindia. Bagaimana denganmu? Apa panggilan jiwamu?"

Aku tidak menjawab. Tak sudi menjawab" (Iksaka, 2014:71)

Peduli Terhadap Kondisi Rakyat Banten

Saat Tokoh utama (TU) melihat 
sosok tahanan di sel paling depan, tahulah dia bahwa orang itu salah seorang yang sangat berpengaruh, punya banyak pengikut. Dan menganggap popor bedil yang dihantam Dirk sangat berlebihan. TU mengingatkan bila seorang yang ditahan Dirk adalah pemimpin agama.

"Pikirkan murid-murid orang ini di luar sana bila tahu pemimpin merekadianiaya."(Iksaka, 2014:75).

Dia menyayangkan kekerasan yang dilakukan oleh wakilnya yang membuat wajahnya lebam dan merantai kedua tangan dan kakinya. Baginya

"Orang tarekat harus didekati secara halus. Sekarang ia telanjur di sini. Hanya ada dua pilihan: Ia pindah ke penjara kabupaten secepatnya atau penjagaan tem pat ini diperkuat" (Iksaka, 2014:74).

TU menyadari jika perlawanan rakyat banten yang bersifat spiritual sangat membahayakan kemapanan pemerintah Hindia Belanda dan keselamatan para pejabat termasuk dirinya. Mengenai bencana Krakatau. Pemerintah tidak alpamenyalurkan bantuan pangan, mengirim penggali kubur, serta mendirikan pos kesehatan.

"Kita perlu juru bicara, mungkin orang setempat, yang bisa menjelaskan" (Iksaka, 2014:75).

\section{Keluar Dari Dinas Tentara Hindia Belanda}

Mengetahui kebejatan penguasa militer Hindia Belanda atas apa yang mereka lakukan terhadap rakyat Tionghoa, Tokoh utama menyesali karier, profesionalitas dan kemampuan militer yang jauh di atas rekan-rekannya. sehingga membuat dirinya mudah terlihat kemudian disalahgunakan oleh penguasa.. perintah tuk mermbunuh Von Imhoff bagi Goedaerd sangat bertentangan dengan hati nuraninya. Baginya tindakan itu Lebih rendah daripada perampok. Perampok menatap mata korbannya, sedang aku menembak dari belakang. Diakhir perenungannya Goedaerd memutuskan

"akan keluar dari dinas, memulai hidup baru”

(Iksaka, 2014:77:112)

\section{SIMPULAN}

Hasil penelitian menujukan bahwa Pertama, kepribadian yang menonjol pada para tokoh utama dalam kumpulan cerpen Semua untuk Hindia karya Iksaka Banu antara lain: Rasional dan mampu menganalisa keadaan kondisi sosial masyarakat saat itu serta tahu apa yang harus dilakukan.

Kedua, aktualisasi diri Para utama dalam kumpulan cerpen Semua untuk Hindia karya Iksaka Banu terdiri dari dua tujuan, yaitu keinginan untuk menyelamatkan orang yang mereka sayangi dan hormati baik yang berkebangsaan Belanda

\section{DAFTAR RUJUKAN}

Aminuddin. 2009. Pengantar Apresiasi Karya Sastra. Bandung: Sinar Baru Algensindo: Bandung.

Fananie, Zainuddin. 2002. Telaah Sastra. Surakarta: Muhammadiyah University Press.

Feist, Jess dan Gregory J.Feist. 2010. Teori Kepribadian. Diterjemahkan kedalam Bahasa Indonesia oleh Handriatno. Jakarta: Salemba Humanika.

Fudyartanta, Ki. 2012. Psikologi Kepribadian: Paradigma Filosofis, Tipologis, Psikodinamik, dan OrganismikHolistik.Yogyakarta: PustakaPelajar.

Goble, Frank G. 1994. Mazhab Ketiga Psikologi Humanistik Abraham 
Maslow. Diterjemahkan ke dalam Bahasa Indonesia oleh Drs. A. Supratiknya. Yogyakarta: Kanisius.

Kartodirjo, Sartono. 1992. Pengantar Sejarah Indonesia Baru : 15001900 Dari Emporium sampai Imperium. Jakarta : Gramedia Pustaka.

Luxemburg dkk. 1986. Pengantar Ilmu Sastra. Diterjemahkan ke dalam Bahasa Indonesia oleh Dick Hartoko. Jakarta: PT Gramedia.

Nurgiyantoro, Burhan. 2009. Teori Pengkajian Fiksi. Yogyakarta: Gajah Mada University Press.

Martono, H. 2013. Nilai-Nilai dalam Kumpulan Cerpen Semua Untuk Hindia Karya Iksaka Banu). http://jurnal.untan.ac.id. Diakses pada tanggal 12 Juli 2018.
Ratna, Nyoman Kutha. 2011. Teori, Metode, dan Teknik Penelitian Sastra: dari Strukturalisme Hingga Postrukturalisme Perspektif Wacana Naratif. Yogyakarta: Pustaka Pelajar.

Ricklefs, M C. Sejarah Indonesia Modern 1200-2004 terj SatrioWahono Dkk. Jakarta : Serambi Ilmu Semesta Gramedia Pustaka.

Sumardjo, Jakob dan Saini K. M. 1997. Apresiasi Kesusastraan. Jakarta: Gramedia Pustaka Utama.

Wellek, Rene \& Austin Warren.1995. Teori Kesusastraan. Diterjemahkan ke dalam Bahasa Indonesia oleh Melani Budianta. Jakarta: Gramedia pustaka Utama. 